\title{
Colaboración científica en investigación agrícola en Colombia
}

\section{Resumen}

Las consideraciones políticas sobre Colombia se encuentran en el centro del interés público global. Los desafíos políticos, económicos y sociales que surgen desde la firma de los acuerdos de paz de La Habana nos son menores; en el centro de estos desafíos, la agricultura juega un papel crucial en la evolución del país, desde una posición de economía de carácter emergente hacia una de carácter consolidado, dentro del club de buenas prácticas de la Organización para la Cooperación y el Desarrollo Económicos (OCDE). La investigación y el desarrollo en agricultura han probado ser un direccionador económico de este sector, $\mathrm{y}$, en ese sentido, este artículo propone un aporte académico basado en un análisis bibliométrico centrado en la identificación de los autores y organizaciones más influyentes de esta disciplina, con base en el mapeo de las redes científicas de citación de artículos durante los últimos 18 años, basado en la información que proporciona la de la base de datos Web of Science (WoS). Las instituciones de Educación Superior, especialmente las universidades, están jugando un rol principal dentro del desarrollo de investigación, innovación y creación de conocimiento en agricultura, en este documento se resalta la importancia de ese rol.

\section{Introducción}

La necesidad de aumentar de forma sostenible la producción agrícola en el ámbito mundial ha fortalecido el enfoque colaborativo dentro de los instrumentos basados en políticas para la promoción de la innovación regional y nacional en agricultura[1]. Los sistemas de innovación agrícola (SIA) son redes de actores (universidades, centros de investigación, entidades territoriales, empresas, ONG) que trabajan de forma colaborativa [2]. Las universidades juegan un papel central en la colaboración entre actores en los Sistemas de Innovación (SI) en el ámbito mundial, por medio de funciones y roles como la intermediación de conocimiento, soportada en su capital social. La heterogeneidad de las redes de colaboración científica es un facilitador de la difusión de la innovación y el impacto de los resultados de investigación. En este artículo se analizan las redes de citación de autores y organizaciones en investigación agrícola en Colombia, como un aporte académico a la comprensión de la productividad e impacto de autores y organizaciones, así como colaboración dentro de esta disciplina. Dentro de los mapas presentados, los nodos representan las unidades de análisis (autores y organizaciones) y los arcos o bordes, las relaciones en las que se centra el tipo de análisis, específicamente, las relaciones de citación.

\section{Métodos}

Se recopiló la información de citaciones de los artículos publicados entre los años 2000 a 2018, por medio de la opción de búsqueda avanzada por país/región, usando los términos $\mathrm{CU}=($ Colombia); y se obtuvo como resultado la identificación de 72.604 artículos. Web of Science clasifica los artículos en algunas categorías seleccionadas[3], y se refinaron los resultados de investigación por subcategorías relacionadas con el agro, con lo cual se identifican 6408 documentos. Para relacionar solo artículos de investigación, se aplican filtros tomando en consideración solo artículos y revisiones, de lo que se obtienen 6282 estudios. Los resultados son clasificados usando un análisis centrado en países, con información de Colombia, y se aplicaron análisis basados en citación y productividad para la evaluación de actividades de colaboración científica. El análisis bibliométrico y el mapeo de redes se desarrollan con base en información estadística de citaciones de autores y organizaciones del censo de los 6282 artículos. El análisis de la citación de autores y organizaciones permite identificar autores influyentes dentro de las redes científicas[4]. El análisis de citas comienza con la selección de los "autores", como unidad de análisis u objeto a estudiar, seguido de la inclusión de organizaciones como un complemento a los análisis mencionados. El mapeo de las redes de citación se desarrolló con el software VOSviewer, el cual se posiciona como la herramienta líder por número de citaciones en el mapeo y visualización científica[5].

\section{Análisis de citación de autores}

En la búsqueda de los autores más influyentes, se presentan y analizan en profundidad los mapas basados en citas de los artículos de mayor impacto de la ciencia agrícola en Colombia. Este análisis se caracteriza por su independencia, dado que se conoce que WoS considera la información de citas como parte de su proceso de asignación de categorías o cuartiles a las revistas indexadas. La figura 1 muestra la red de los 693 autores más citados en investigación agrícola dentro de la muestra. Esta información de citación es usada en el análisis de cocitación de autores, para mostrar el relacionamiento entre los autores altamente citados. El ranking de los 10 autores más citados se muestra en la tabla 1.

ISSN impreso: 1657 - 4583, ISSN en línea: 2145 - 8456. CC BY-ND 4.0 (c) (i) $९$

E. Romero-Riaño, A. Pertuz-Comas., "Colaboración científica en investigación agrícola en Colombia," Rev. UIS Ing., vol. 18, no. 3, pp. 10-14, 2019. doi: 10.18273/revuin.v18n3-2019022 
Dentro de la estructura de esta red, resalta la posición central del profesor Rao I., quien, junto con los autores Blair M. y Beebe S. conforman el cluster con mayor influencia dentro de la red (color violeta), debido a su productividad (cantidad de documentos) e impacto (número de citas).

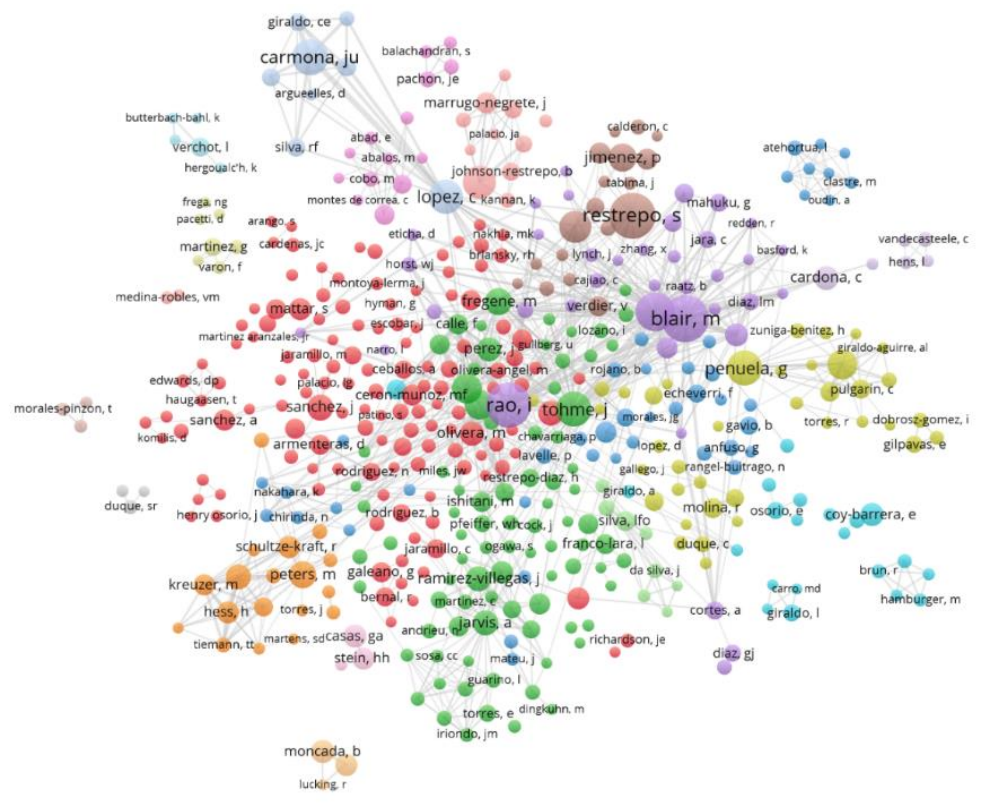

Figura 1. Mapa de citación de autores en investigación agrícola en Colombia

La tabla 1 resume los datos del número de citaciones, el país de localización y la filiación institucional de los diez principales autores ordenados por el número de citaciones dentro de WoS. De acuerdo con el indicador del número de citaciones, el autor más influyente dentro de la red de investigación en agricultura en Colombia es Blair MW. El profesor Blair de la Universidad de Tennessee presenta un total de 89 documentos en la muestra, y 132 vínculos con otros investigadores de la red (fig. 1).

Tabla 1. Ranking de autores más citados en investigación agrícola en Colombia

\begin{tabular}{|l|c|l|l|}
\hline \multicolumn{1}{|c|}{ Autor } & Citaciones & \multicolumn{1}{|c|}{$\begin{array}{c}\text { País de } \\
\text { localización }\end{array}$} & \multicolumn{1}{|c|}{ Organización } \\
\hline Blair M. & 3832 & Estados Unidos & $\begin{array}{l}\text { Department of Agricultural and Environmental } \\
\text { Sciences, Tennessee State University }\end{array}$ \\
\hline Beebe S. & 2891 & Colombia & Centro de Investigación en Agricultura Tropical (CIAT) \\
\hline Tohme J. & 2346 & Colombia & Centro de Investigación en Agricultura Tropical (CIAT) \\
\hline Rao I & 1978 & Colombia & Centro de Investigación en Agricultura Tropical (CIAT) \\
\hline Rondon M. & 1260 & Colombia & Centro de Investigación en Agricultura Tropical (CIAT) \\
\hline Jarvis A. & 1128 & Colombia & $\begin{array}{l}\text { CGIAR Research Program on Climate Change, } \\
\text { Agriculture and Food Security (CCAFS), UK }\end{array}$ \\
\hline Thornton P. & 959 & Kenia & $\begin{array}{l}\text { International Livestock Research Institute (ILRI) } \\
\text { CGIAR }\end{array}$ \\
\hline Ceballos H. & 949 & Colombia & Universidad Nacional de Colombia (UNAL) \\
\hline $\begin{array}{l}\text { Torres-Palma } \\
\text { RA }\end{array}$ & 927 & Colombia & Universidad de Antioquia (UDEA) \\
\hline
\end{tabular}

Las filiaciones institucionales más frecuentes dentro del grupo de 10 autores muestran al Centro Internacional de Agricultura Tropical (CIAT) y al Science for humanity's greatest challenges (CGIAR) como las organizaciones con mayor influencia dentro de esta red de investigación. Dentro de las universidades colombianas, resaltan la Universidad Nacional de Colombia y la Universidad de Antioquia como las organizaciones con mayor productividad, impacto y nivel de capital social representado en número de vínculos dentro de la muestra. 


\section{Análisis de citación de organizaciones}

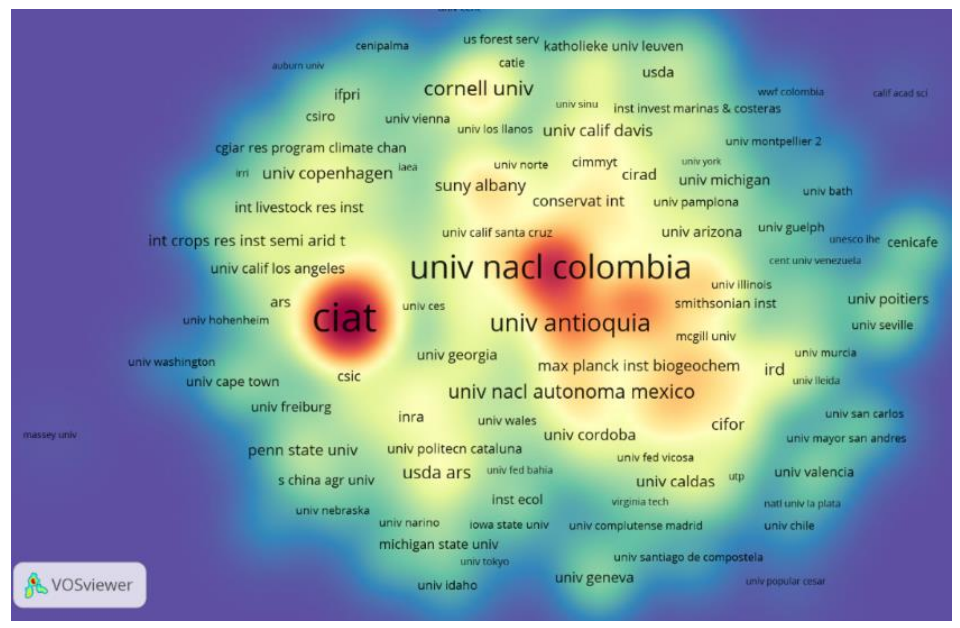

Figura 2. Mapa de citación de organizaciones en investigación agrícola en Colombia.

La figura 2 muestra la red de citación de organizaciones en investigación agrícola en Colombia. Esta visualización de densidad muestra en rojo los ítems o nodos con mayor número de citaciones. La Universidad Nacional de Colombia (UNAL) es la organización con mayor productividad dentro de la red, con un total de 1560 artículos, seguida por el CIAT, con 804 documentos. La posición central de la UNAL en la red de citación se fundamenta en el número de vínculos con otros nodos (372), así como en el indicador de fortaleza dentro de la red (3520). La posición y los vínculos que representan el capital social de la UNAL muestran el carácter influyente de esta organización en la investigación agrícola.

Sin embargo, como se observa en la figura 2, el nodo con mayor intensidad del número de citaciones es el Centro de Investigación en Agricultura Tropical (CIAT), con un total de 21.277 citaciones, que contrastan con las 12.273 de la UNAL. El CIAT es un centro de investigación que forma parte del Sistema CGIAR, que es la red mundial más grande de innovación agrícola. El CIAT es una organización que realiza investigación colaborativa para mejorar la productividad agrícola y el manejo de los recursos naturales en países en vía de desarrollo. Esta fortaleza en el número de citaciones del CIAT está sustentada en proporción al capital social de sus investigadores, cuyos vínculos de sus redes individuales presentan mayor heterogeneidad (medida en el número de autores de diferentes países en su red). Esta diversidad se considera una fuente potencial de impacto dentro de las redes sociales de investigadores.

La figura 3 muestra la centralidad y vínculos de la universidad del ámbito regional con mayor número de citaciones dentro de la investigación agrícola en Colombia, la Universidad de Antioquia.

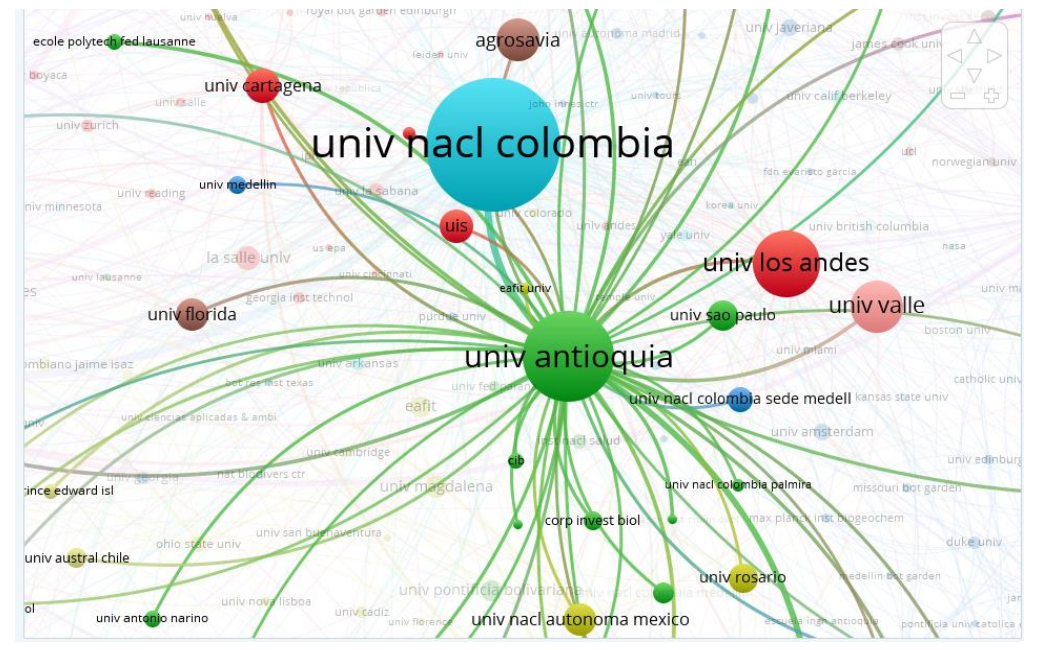

Figura 3. Red de citación de universidades nacionales en investigación agrícola en Colombia. 
La Universidad de Antioquia presenta alta productividad, representada en un total de 782 artículos e impacto con un total de 902 citaciones. Resalta su posición dentro de la red, por la cercanía con la UNAL y sus vínculos con universidades de su territorio (Universidad de Medellín, EAFIT y Universidad Nacional sede Medellín) junto a otras universidades regionales de carácter público, la Universidad del Valle y la Universidad Industrial de Santander.

\section{Discusión y conclusiones}

El presente artículo analiza las redes de citación de autores y organizaciones en investigación agrícola en Colombia, como un aporte académico a la comprensión de la productividad e impacto de la producción científica dentro del área agrícola. Se identifican bajos niveles de heterogeneidad dentro de la red de citación de organizaciones en investigación Agrícola en Colombia. En el ámbito nacional, el CIAT y la UNAL son las organizaciones con mayor influencia. A nivel regional, la Universidad de Antioquía, la Universidad del Valle y la Universidad Industrial de Santander muestran cercanía con la UNAL. Estas cuatro instituciones conforman el grupo de las universidades oficiales con mayor productividad científica e impacto en investigación. Resalta la baja diversidad de las redes de organizaciones, donde el $81 \%$ de los nodos de la red son universidades y el $9 \%$ son centros de investigación en el agro. De los grupos de interés típicos de los SIA, no tienen participación significativa en la red las empresas, entidades territoriales y agremiaciones de productores.

Los autores más influyentes dentro de la red de investigación científica de la muestra de artículos, con filiación institucional a universidades son Ceballos (UNAL) y Torres-Palma (UDEA). Estos autores tienen el potencial de desplegar un rol mediador entre las instituciones y autores regionales, con las redes mundiales de investigación agrícola, así como de generar lazos con otros grupos de interés, tales como empresas y organizaciones de productores.

\section{Referencias}

[1] A. Ghoneim and I. Ezz, "The increasing complexity of IS cost identification and management in the context of open innovation," in 15th International Business Information Management Association Conference, IBIMA 2010, 2010, vol. 3, pp. 1940-1954.

[2] L. Klerkx and N. Aarts, "The interaction of multiple champions in orchestrating innovation networks : Conflicts and complementarities," Technovation, vol. 33, pp. 193-210, 2013. doi: 10.1016/j.technovation.2013.03.002

[3] W. Chen, W. Liu, Y. Geng, M. T. Brown, C. Gao, and R. Wu, "Recent progress on emergy research: A bibliometric analysis," Renew. Sustain. Energy Rev., vol. 73, pp. 1051-1060, 2017. doi: 10.1016/j.rser.2017.02.041

[4] G. González Alcaide, J. C. Valderrama Zurián, R. Aleixandre Benavent, A. Alonso Arroyo, J. I. de Granda Orive, and S. Villanueva Serrano, "Redes de coautoría y colaboración de las instituciones españolas en la producción científica sobre drogodependencias en biomedicina 1999-2004,” Trastor. Adict., vol. 8, no. 2, pp. 78-114, Jun. 2006.

[5] G. M. Martínez-Toro, D. Rico-Bautista, E. Romero-Riaño, C. J. Galeano-Barrera, C. D. Guerrero, and J. A. Parra-Valencia, "Analysis of the intellectual structure and evolution of research in human-computer interaction: A bibliometric analysis ," RISTI - Rev. Iber. Sist. e Tecnol. Inf., no. E17, pp. 363-378, 2019.

\section{Efrén Romero Riaño}

Profesor investigador EEIE

Grupo de Investigación Innotec-UIS

\author{
Alberto David Pertuz Comas \\ Editor \\ Universidad Industrial de Santander
}




\title{
Scientific collaboration on agricultural research in Colombia
}

\begin{abstract}
Political considerations on Colombia are at the center of the global public interest. The political, economic and social challenges that arise since the signing of the peace agreements in Havana are less; at the center of these challenges, agriculture plays a crucial role in the evolution of the country, from an economic position of a nature emerging towards a consolidated one, within the club of good practices of the Organization for Economic Cooperation and Development (OECD). Research and development in agriculture has proven to be an economic leader in this sector, and in this sense, this article proposes an academic contribution based on a bibliometric analysis focused on the identification of the most influential authors and organizations of this discipline, in regards to the mapping of scientific articles citation networks during the last 18 years, based on the information provided by the Web Of Science database, WoS. Higher education institutions, especially universities, are playing a leading role in the development of research, innovation and knowledge creation in agriculture. This document highlights the importance of that role.
\end{abstract}

\section{Introduction}

The need to sustainably increase agricultural production worldwide has strengthened the collaborative approach within policy-based instruments for the promotion of regional and national innovation in agriculture [1]. The agricultural innovation systems, SIA, are networks of actors (universities, research centers, territorial entities, companies, NGOs) that work collaboratively [2]. Universities play a central part in the collaboration between actors in the Innovation Systems, SI, worldwide, through functions and roles like knowledge intermediation, supported by their social capital. The heterogeneity of scientific collaboration networks is a facilitator of the diffusion of innovation and the impact of research results. In this article, we analyze the citation networks of authors and organizations in agricultural research in Colombia as an academic contribution to the understanding of the productivity and impact of authors and organizations as well as a collaboration in this discipline. In the presented maps, the nodes represent the units of analysis (authors and organizations) and the arcs or edges, the relationships in which the type of analysis is focused, especifically, the citation relations.

\section{Methods}

The information regarding the citations of the articles published from 2000 to 2018 was compiled through the advanced search option by Country / Region, using the terms: CU = (Colombia), obtaining , as a result, the identification of 72,604 articles. Web of Science classifies the articles into selected categories [3], and the results of the research were refined by subcategories related to agriculture, which identified 6,408 documents. To relate only research articles, filters are applied considering just articles and reviews, gathering 6,282 studies. The results are classified in a country focus with information from Colombia, and attention and productivity analyses are applied for the evaluation of scientific collaboration activities. The bibliometric analysis and the network map are based on statistical information of citations of authors and organizations from the 6,282 articles. The analysis of the citations of authors and organizations allows identifying influential authors within the scientific networks [4]. The analysis of the citations begins with the selection of the "authors," as the unit of analysis or object of a study and followed up by the inclusion of the organizations as a complement of the pertinent analyzes. The map of the citation networks can be seen with the VOSviewer software, which is positioned as the leading tool in the number of citations, on the map and scientific publication [5].

\section{Authors' citation analysis}

In the search for the most influential authors, maps based on citations of the articles with the greatest impact of agricultural science in Colombia are presented and analyzed in depth. This analysis is characterized by its independence since it is well-known that WoS considers citing information as part of its process of assigning categories or quartiles to indexed journals. Figure 1 shows the network of the 693 most cited authors in agricultural research within the sample. This citation information is used in the co-citation analysis of authors to show the relationship between the highly cited authors. The ranking of the 10 most cited authors is displayed in Table 1.

Within the structure of this network, the central position of Professor Rao, I stands out, who together with the authors Blair, $\mathrm{M}$ and Beebe, $\mathrm{S}$ makes up the cluster of the most influential within the network (violet color) due to their productivity (number of documents) and impact (number of citations). 


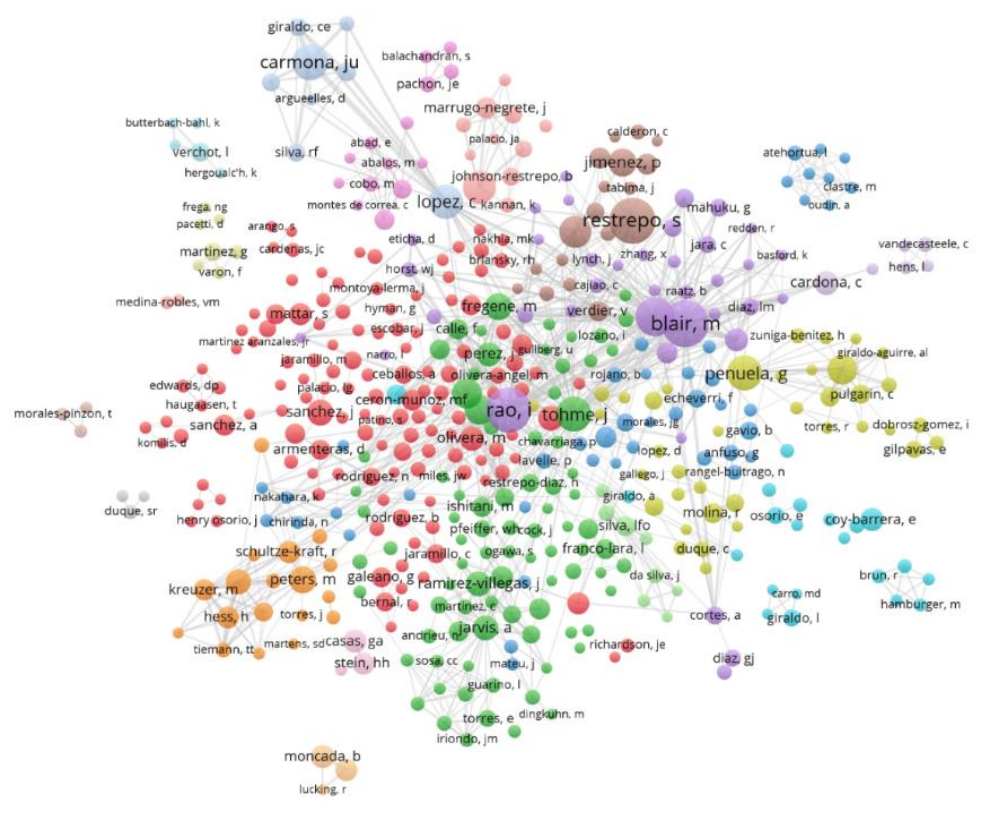

Figure 1. Citation map of authors in agricultural research in Colombia.

Table 1 summarizes the data on the number of citations, the country of location and the institutional affiliation of the ten main authors ordered by the number of citations within WoS. According to the indicator of the number of citations, the most prominent author within the agricultural research network in Colombia is Blair, MW. Professor Blair of the University of Tennessee presents a total of 89 documents in the sample and 132 links with other researchers in the network (Figure 1).

Table 1. Ranking of the most cited authors in agricultural research in Colombia

\begin{tabular}{|l|c|l|l|}
\hline \multicolumn{1}{|c|}{ Author } & Citations & \multicolumn{1}{c|}{$\begin{array}{c}\text { Country of } \\
\text { location }\end{array}$} & \multicolumn{1}{c|}{ Organization } \\
\hline Blair, $\mathrm{m}$ & 3832 & Estados Unidos & $\begin{array}{l}\text { Department of Agricultural and Environmental Sciences, } \\
\text { Tennessee State University }\end{array}$ \\
\hline Beebe, $\mathrm{s}$ & 2891 & Colombia & Centro de Investigación en Agricultura Tropical, CIAT \\
\hline Tohme, $\mathrm{j}$ & 2346 & Colombia & Centro de Investigación en Agricultura Tropical, CIAT \\
\hline Rao, $\mathrm{i}$ & 1978 & Colombia & Centro de Investigación en Agricultura Tropical, CIAT \\
\hline Rondon, $\mathrm{m}$ & 1260 & Colombia & Centro de Investigación en Agricultura Tropical, CIAT \\
\hline Jarvis, a & 1128 & Colombia & $\begin{array}{l}\text { CGIAR Research Program on Climate Change, } \\
\text { Agriculture and Food Security (CCAFS), UK }\end{array}$ \\
\hline Thornton, $\mathrm{p}$ & 959 & Kenia & International Livestock Research Institute (ILRI) CGIAR \\
\hline Ceballos, h & 949 & Colombia & Universidad Nacional de Colombia (UNAL) \\
\hline Torres-palma, ra & 927 & Colombia & Universidad de Antioquia (UDEA) \\
\hline
\end{tabular}

The most frequent institutional affiliations within the group of the 10 authors exhibits the International Center for Tropical Agriculture (CIAT) and CGIAR: Science for Humanity's Greatest Challenges as the organizations with the most influence within this research network. Within the Colombian universities, Universidad Nacional de Colombia (UNAL) and Universidad de Antioquia stand out as the organizations with the highest productivity, impact and level of social capital represented by the number of links within the sample. 


\section{Organization citation analysis}

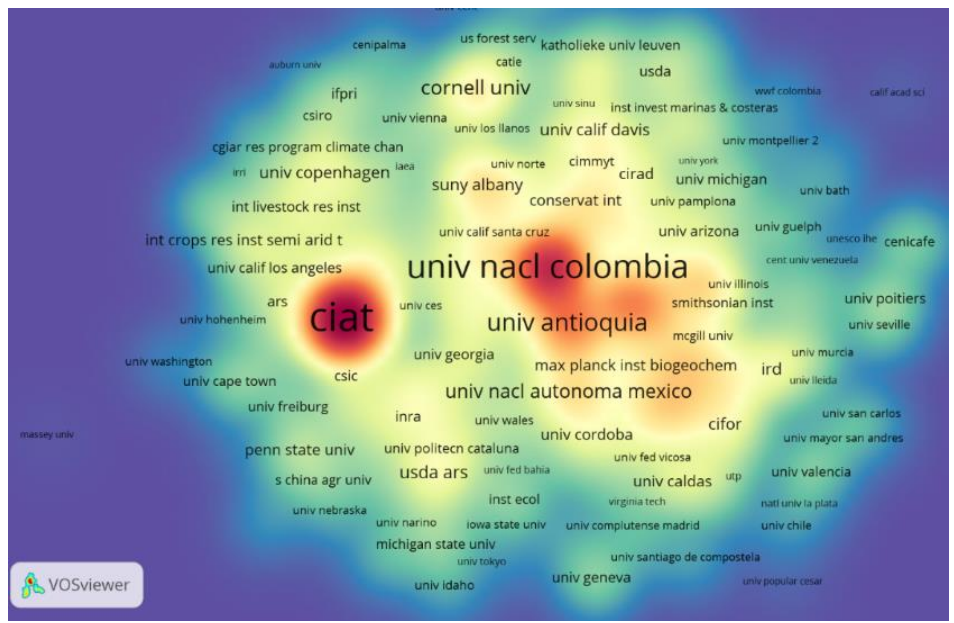

Figure 2. Citation map of organizations in agricultural research in Colombia.

Figure 2 shows the citation network of organizations in agricultural research in Colombia. This density display shows in red the items or nodes with the highest number of citations. The UNAL is the organization with the highest productivity within the network with a total of 1,560 articles, followed by CIAT, with 804 documents. The central position of the UNAL in the citation network is based on the number of links with other nodes (372) as well as on the strength indicator within the network (3520). The position and the links that represent the social capital of the UNAL show the influential nature of this organization in agricultural research.

However, as it can be seen in Figure 2, the node with the highest intensity of the number of citations is CIAT with a total of 21,277 citations, which contrasts with the 12,273 of the UNAL. CIAT is a research center that is part of the CGIAR System, which is the largest global network of agricultural innovation. CIAT is an organization that conducts collaborative research to improve agricultural productivity and the management of natural resources in developing countries. This strength in the number of CIAT citations is supported in proportion to the social capital of its researchers, whose links in their individual networks show greater heterogeneity (measured in the number of authors from different countries in their network). This diversity is considered a potential source of impact within the social networks of researchers.

Figure 3 demonstrates the centrality and links of the university at the regional level with the highest number of citations within agricultural research in Colombia, the University of Antioquia.

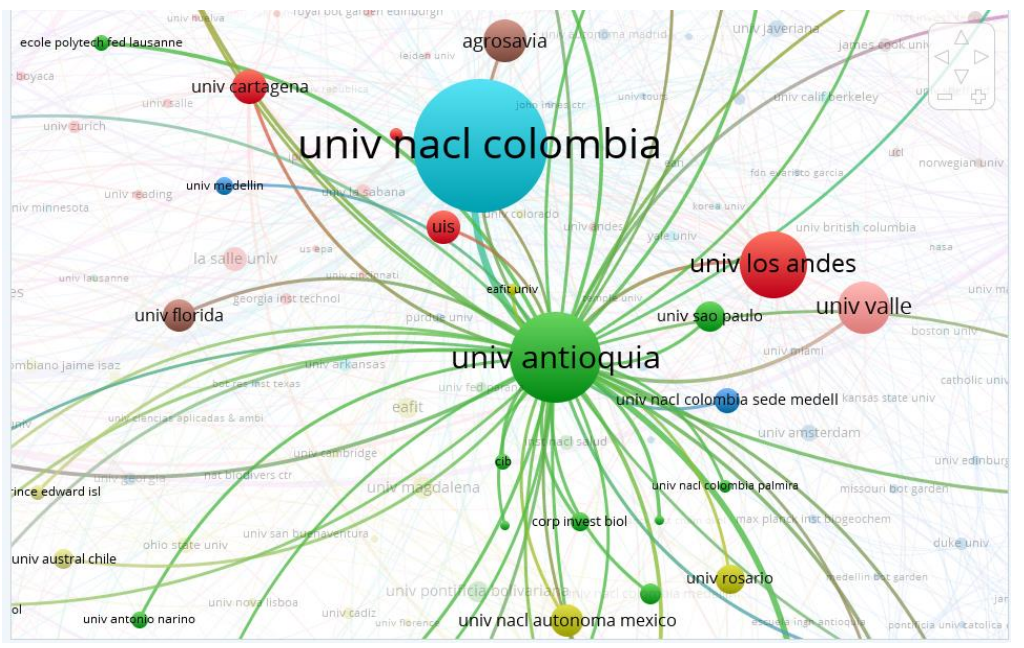

Figure 3. Citation network of regional universities in agricultural research in Colombia. 
The Universidad de Antioquia presents high productivity, represented in a total of 782 articles and impact with a total of 902 citations. It highlights its position within the network due to its closeness to UNAL and its links with universities in its territory (Universidad de Medellín, EAFIT and Universidad Nacional, Medellín) together with other regional public universities, Universidad del Valle and the Universidad Industrial de Santander.

\section{Discussion and conclusions}

This article analyzes the citation networks of authors and organizations in agricultural research in Colombia as an academic contribution to the understanding of the productivity and impact of scientific production within the agricultural area. Low levels of heterogeneity are identified within the citation network of organizations in research in this field in Colombia. At the national level, CIAT and UNAL are the organizations with the greatest influence. At the regional level, the Universidad de Antioquia, the Universidad del Valle and the Universidad Industrial de Santander, show closeness to the UNAL. These four institutions make up the group of official universities with the highest scientific productivity and research impact. It highlights the low diversity of the networks of organizations where $81 \%$ of the nodes of the network are universities, and $9 \%$ are research centers in agriculture. Of the typical interest groups of the SIA, they do not have significant participation in the network, companies, territorial entities and producer associations.

The most influential authors within the scientific research network of the sample of articles, with institutional affiliation to universities, are Ceballos (UNAL) and Torres-Palma (UDEA). These authors have the potential to deploy a mediating role among regional institutions and authors, with global agricultural research networks as well as to generate links with other interest groups such as companies and producer organizations.

\section{References}

[1] A. Ghoneim and I. Ezz, "The increasing complexity of IS cost identification and management in the context of open innovation," in 15th International Business Information Management Association Conference, IBIMA 2010 , 2010, vol. 3, pp. 1940-1954.

[2] L. Klerkx and N. Aarts, "The interaction of multiple champions in orchestrating innovation networks : Conflicts and complementarities," Technovation, vol. 33, pp. 193-210, 2013.

[3] W. Chen, W. Liu, Y. Geng, M. T. Brown, C. Gao, and R. Wu, "Recent progress on emergy research: A bibliometric analysis," Renew. Sustain. Energy Rev., vol. 73, pp. 1051-1060, 2017.

[4] G. González Alcaide, J. C. Valderrama Zurián, R. Aleixandre Benavent, A. Alonso Arroyo, J. I. de Granda Orive, and S. Villanueva Serrano, "Redes de coautoría y colaboración de las instituciones españolas en la producción científica sobre drogodependencias en biomedicina 1999-2004,” Trastor. Adict., vol. 8, no. 2, pp. 78-114, Jun. 2006.

[5] G. M. Martínez-Toro, D. Rico-Bautista, E. Romero-Riaño, C. J. Galeano-Barrera, C. D. Guerrero, and J. A. Parra-Valencia, "Analysis of the intellectual structure and evolution of research in human-computer interaction: A bibliometric analysis ," RISTI - Rev. Iber. Sist. e Tecnol. Inf., no. E17, pp. 363-378, 2019.

Efrén Romero Riaño

Profesor investigador EEIE

Grupo de Investigación Innotec-UIS

\author{
Alberto David Pertuz Comas \\ Editor \\ Universidad Industrial de Santander
}

